\title{
KERAGAAN PETERNAKAN AYAM SENTUL DI KABUPATEN CIAMIS
}

\section{THE PERFORMANCE OF SENTUL CHICKEN FARMING IN CIAMIS DISTRICT}

\author{
Sudrajat*, Agus Yuniawan Isyanto \\ Fakultas Pertanian, Universitas Galuh \\ *E-mail: sudradjatlebsi@gmail.com \\ (Diterima 08-07-2018; Disetujui 25-07-2018)
}

\begin{abstract}
ABSTRAK
Penelitian dilaksananakan dengan menggunakan metode studi kepustakaan. Data yang digunakan berupa data sekunder yang diperoleh melalui penelurusan kepustakaan yang berkaitan dengan penelitian ini. Data yang diperoleh selanjutnya dianalisis secara deskriptif untuk menggambarkan keragaan peternakan ayam Sentul di Kabupaten Ciamis. Penelitian menunjukkan bahwa ayam Sentul merupakan ayam asli Kabupaten Ciamis yang memiliki keunggulan dalam pertumbuhan bobot badan dan produksi telur sehingga memiliki potensi untuk dikembangkan dalam upaya meningkatkan pendapatan peternak.
\end{abstract}

Kata kunci: Keragaan, Ayam Sentul, Kabupaten Ciamis

\section{ABSTRACT}

The research was conducted by using literature study method. The data used in the form of secondary data obtained through literature review related to this research. The data obtained then analyzed descriptively to describe the performance of Sentul chicken farm in Ciamis Regency. Research shows that Sentul chicken is the original chicken of Ciamis Regency which has an advantage in body weight growth and egg production so it has the potential to be developed in an effort to increase the income of farmers.

Keywords: Performance, Sentul Chicken, Ciamis District

\section{PENDAHULUAN}

Kebutuhan masyarakat terhadap hasil ternak seperti daging, susu, dan telur mengalami peningkatan seiring dengan peningkatan populasi penduduk, peningkatan pendidikan dan pengetahuan masyarakat tentang pentingnya gizi (Wiranata, dkk., 2017).

Ayam lokal memiliki potensi untuk dikembangkan sebagai sumber protein hewani guna mendukung kemandirian pangan nasional. Namun pertumbuhan dan kualitas produksi ayam lokal cenderung masih rendah karena sistem budidaya yang dilaksanakan masih secara tradisional. Upaya peningkatan pertumbuhan dan produktivitas ayam lokal tidak hanya dilaksanakan dari sisi pakan dan manajemen pemeliharaan, namun perlu juga dilakukan perbaikan mutu genetik melalui proses seleksi dan persilangan dengan tetap mempertahankan sifat-sifat khas dari 
ayam lokal tersebut (Mariandayani, dkk., 2017).

Ayam kampung merupakan ayam asli Indonesia yang telah dipelihara dan dikembangkan oleh masyarakat, terutama yang tinggal di pelosok-pelosok pedesaan. Ayam-ayam tersebut telah beradaptasi dengan kondisi lingkungan pemeliharaan yang sederhana (Susanto dan Suliswanto, 2013).

Peran ayam lokal dalam perekonomian keluarga dan masyarakat masih cukup tinggi, khususnya di pedesaan. Ayam lokal dipelihara oleh masyarakat terutama sebagai tabungan keluarga yang dapat dijual kapan saja pada saat memerlukan uang tunai. Telur yang dihasilkan selain untuk ditetaskan, juga untuk dikonsumsi dalam upaya perbaikan gizi keluarga (Suhardi, 2011). Peran ayam lokal (kampung) atau ayam buras (bukan ras) dalam kehidupan masyarakat pedesaan cukup erat dengan perkembangan budaya masyarakat, sekaligus dijadikan sumber konsumsi daging dan telur. Produk pangan yang berasal dari ayam lokal memiliki posisi yang baik, karena karakteristik yang khas yang terdapat di dalamnya yang secara umum disukai oleh masyarakat (Akhadiarto, 2017).
Telur ayam kampung sangat digemari masyarakat, namun kemampuan produksi telur dari ayam kampung masih terbatas (Muharlien dan Nurgiartiningsih, 2015). Telur dan daging ayam lokal memiliki harga yang lebih tinggi dibandingkan dengan telur dan daging ayam ras sehingga layak untuk dibudidayakan. Kendala dalam budidaya ayam lokal antara lain adalah laju pertumbuhan bobot badan yang relatif lambat, rendahnya produksi telur, dan sifat mengeram yang tinggi (Mariandayani, dkk., 2017).

\section{TINJAUAN PUSTAKA}

Indonesia memiliki ayam lokal yang memiliki keragaman dan variasi dalam penampilan produksi yang disebabkan oleh sistem pemeliharaan, perkawinan dan adaptasi lingkungan. Salah satu ayam lokal di Indonesia adalah ayam Sentul (Mariandayani, dkk., 2013). Pangsa pasar ayam lokal berbeda dengan ayam ras. Kehadiran dan peningkatan populasi ayam lokal tidak akan merebut pangsa pasar ayam ras, karena ayam lokal memiliki preferensi dan konsumen sendiri. Program pemerintah untuk percepatan pengembangan ayam lokal melalui berbagai tahapan perlu disambut 
dengan baik. Dengan pengembangan ayam lokal yang terarah dari pemerintah bersama pemangku kepentingan, pamor ayam lokal di masa depan akan jauh lebih baik. Upaya ini akan mengurangi ketergantungan kepada pihak luar, memperluas lapangan kerja di perdesaan, menekan urbanisasi, dan semakin mendorong berkembangya bisnis kuliner berbahan baku ayam lokal, karena adanya jaminan (Akhadiarto, 2017).

Ayam kampung merupakan salah satu alternatif yang digunakan untuk memenuhi kebutuhan daging unggas. Ayam kampung disukai orang karena dagingnya yang kenyal dan berisi, tidak lembek dan tidak berlemak sebagaimana ayam ras. Ayam kampung terdiri atas berbagai rumpun atau galur, diantaranya ayam Sentul. Ayam sentul merupakan ayam asli Indonesia yang langka dan memiliki potensi dikembangkan sebagai ayam penghasil daging. Ayam Sentul memiliki performans yang baik dalam tingkat produktifitasnya (daging, telur), bahkan lebih baik dibandingkan dengan beberapa rumpun ayam lokal lain, sehingga ayam Sentul dapat dikatakan termasuk tipe dwiguna (Indra, dkk., 2015). Berdasarkan warna bulunya ayam Sentul dibedakan menjadi 6 jenis, yaitu
Sentul Batu (abu kehitaman), Sentul Abu (abu polos), Sentul Debu (abu seperti debu), Sentul Emas (abu kekuningan), Sentul Geni (abu kemerahan) dan Sentul Jambe (abu dengan merah jingga) (Meyliyana, dkk. 2013).

Ayam Sentul merupakan ayam lokal asli dari kabupaten Ciamis yang dapat dimanfaatkan sebagai penghasil daging dan telur. Ayam Sentul saat ini biasanya dipelihara sebagai penghasil daging. Umumnya, Ayam Sentul yang dipelihara secara tradisional dipotong pada umur 12 minggu, sedangkan Ayam Sentul yang dipelihara secara intensif bisa dipotong pada umur 8-10 minggu (Ermansyah, dkk., 2015).

Ayam Sentul memiliki karakteristik berupa pertumbuhan bobot badan yang lebih cepat, lebih tahan terhadap penyakit, dan produksi telur yang relatif lebih tinggi apabila dibandingkan dengan ayam buras lainnya. Dalam satu periode peneluran dihasilkan telur sebanyak 1018 butir, fertilitas di atas $80 \%$, dan daya tetas tinggi yaitu 70-80 \% (Widjastuti, 1996 dalam Widjastuti, 2009).

Kinerja produksi telur ayam Sentul cukup baik dimana dapat menghasilkan lebih dari 100 butir telur per tahun yang lebih tinggi jika dibandingkan dengan 
produksi telur ayam kampung (70 butir/tahun). Pertumbuhan ayam Sentul juga tergolong baik dimana pada umur 10 minggu dapat mencapai bobot sekitar 1 (satu) kilogram atau 100-200 gram lebih tinggi jika dibandingkan dengan pertumbuhan ayam kampung (TROBOS, 2010 dalam Hidayat dan Sopiyana, 2010).

Konsep efisiensi mencakup tiga pengertian, yaitu efisiensi teknis, alokatif dan ekonomi. Efisiensi teknis mencerminkan kemampuan petani untuk memperoleh output maksimal dari sejumlah input tertentu pada tingkat penggunaan teknologi produksi yang sama; atau memperoleh output yang sama dengan menggunakan input yang lebih kecil pada tingkat penggunaan teknologi produksi yang sama. Efisiensi alokatif mencerminkan kemampuan relatif dari petani dalam menggunakan input dengan proporsi yang optimal pada masingmasing tingkat harga input dan teknologi tertentu sehingga dihasilkan output dan keuntungan yang maksimal. Penggabungan efisiensi teknis dan alokatif menghasilkan efisiensi ekonomi yang merupakan perkalian antara efisiensi teknis dan alokatif (Yoko, dkk., 2014).
Menurut Triastono, dkk. (2013) dalam Isyanto, dkk., (2016), efisiensi usaha dapat didekati dengan menggunakan analisis $\mathrm{R} / \mathrm{C}$ dengan persamaan: $\mathrm{E}=\mathrm{R} / \mathrm{C}$, dimana $\mathrm{E}$ adalah efisiensi usaha, $\mathrm{R}$ adalah Return (Penerimaan), dan C adalah Cost (Biaya). Jika $\mathrm{R} / \mathrm{C}>1$ berarti efisien, $\mathrm{R} / \mathrm{C}=1$ berarti keuntungan bernilai nol, dan R/C $<1$ berarti inefisien. Semakin besar nilai $\mathrm{R} / \mathrm{C}$, maka semakin besar tingkat efisiensinya.

Motivasi didefinisikan sebagai satu kekuatan dalam diri seseorang yang mendorong atau menggerakkannya untuk memenuhi kebutuhan dan keinginan dasarnya (Yorks, 2001: 21 dalam Andjarwati, 2015). Menurut Rivai (2009) dalam Marpaung (2013), motivasi adalah sesuatu hal yang menyebabkan dan yang mendukung tindakan atau perilaku seseorang.

Faktor sumberdaya manusia yang dimiliki petani adalah faktor fisik dan non fisik. Faktor non fisik yang menyangkut mental, sikap dan persepsi petani tergantung kepada minat dan motivasi. Tanpa adanya minat dan motivasi yang tinggi dari petani, maka sumberdaya yang dimiliki dan upaya 
yang dilakukannya menjadi tidak berarti (Afriani, dkk., 2014).

Menurut Sumarto (2009) dalam Peranginangin (2014), partisipasi memiliki makna suatu proses ketika warga (sebagai individu, kelompok sosial dan organisasi) mengambil peran serta ikut memengaruhi proses perencanaan, pelaksanaan, dan pemantauan kebijakankebijakan yang langsung berdampak pada kehidupan mereka.

Pada dasarnya partisipasi itu dilandasi dengan adanya pengertian bersama dan adanya pengertian tersebut adalah karena diantara orang-orang itu saling berkomunikasi dan berinteraksi sesamanya. Dalam menggalang peran serta semua pihak itu diperlukan; (1) terciptanya suasana yang bebas atau demokratis dan (2) terbinanya kebersamaan. Partisipasi masyarakat dalam pembangunan, ikut dalam kegiatan perencanaan pembangunan dan ikutserta pemanfaatan dan menikmati hasil-hasil pembangunan (Melis, dkk., 2016).

\section{METODE PENELITIAN}

Penelitian dilaksananakan dengan menggunakan metode studi kepustakaan. Menurut Sugiyono (2012), studi kepustakaan merupakan kajian teoritis, referensi serta literatur ilmiah lainnya yang berkaitan dengan budaya, nilai dan norma yang berkembang pada situasi sosial yang diteliti. Nazir (2005) menyatakan bahwa studi kepustakaan atau studi literatur, selain dari mencari sumber data sekunder yang akan mendukung penelitian, juga diperlukan untuk mengetahui sampai sejauh mana ilmu yang berhubungan dengan penelitian telah berkembang, serta sampai sejauh mana terdapat kesimpulan dan generalisasi yang pernah dibuat sehingga situasi yang diperlukan dapat diperoleh.

Data yang digunakan berupa data sekunder yang diperoleh melalui penelurusan kepustakaan yang berkaitan dengan penelitian ini. Data yang diperoleh selanjutnya dianalisis secara deskriptif untuk menggambarkan keragaan peternakan ayam Sentul di Kabupaten Ciamis.

\section{HASIL DAN PEMBAHASAN}

Ayam kampung merupakan jenis ayam lokal yang dagingnya banyak disukai oleh konsumen karena memiliki tekstur daging yang lebih padat dan rasa yang lebih gurih, namun tingginya minat memelihara ayam kampung belum bisa mengimbangi tingginya kebutuhan 
konsumen terhadap daging ayam kampung. Hal ini disebabkan oleh faktorfaktor yang menjadi hambatan dalam usaha pemeliharaan ayam kampung, antara faktor ransum (Royani, 2016).

Penelitian Royani menunjukkan bahwa subtitusi ransum ayam kampung komersil dengan jagung menunjukkan pengaruh positif yang nyata terhadap nilai Income Over Feed and Chick Cost. Income over feed cost dihitung menggunakan rumus total pendapatan dikurangi pengeluaran ransum.

Hasil penelitian Ermansyah, dkk., (2015) menunjukkan bahwa pemberian tepung ampas tahu hingga tingkat $40 \%$ dalam ransum masih memberikan pengaruh yang baik terhadap bobot potong dan bobot karkas Ayam Sentul, namun pemberian ampas tahu sebesar $10 \%$ memberikan nilai income over feed cost yang paling tinggi. Limbah industri seperti ampas tahu memiliki harga yang relatif lebih murah, tetapi masih memiliki kandungan nutrien yang baik untuk produksi dan kesehatan ternak itu sendiri. Ransum yang diharapkan peternak adalah ransum yang murah tetapi dapat menghasilkan performa ayam yang baik, sehingga memberikan keuntungan yang maksimal.

Penelitian Hidayat, dkk. (2015) menunjukkan bahwa suplementasi 1,5 $\mathrm{g}$ $\mathrm{ZnO} / \mathrm{kg}$ ransum mengandung dedak padi tinggi meningkatkan deposisi lemak abdominal ayam Sentul-G3. Praktik pemanfaatan dedak padi secara intensif oleh para peternak ayam lokal, termasuk peternak ayam Sentul marak dilakukan. Peternak ayam lokal di Indonesia sudah biasa mencampurkan dedak padi dengan ransum komersial untuk menekan biaya pakan. Sementara itu, penggunaan dedak padi dalam ransum ayam dibatasi beberapa faktor, diantaranya adalah asam fitat yang merupakan bentuk penyimpanan utama phosfor dalam tanaman (P-Asam fitat). Ternak unggas tidak mampu mencerna asam fitat karena tidak memiliki fitase dalam saluran pencernaannya sehingga melalui penambahan fitase ke dalam ransum unggas diharapkan dapat memecah ikatan asam fitat dalam saluran pencernaan dan mengakibatkan meningkatnya absorpsi mineral, asam amino, dan protein.

Penelitian Fadly, dkk. (2016) menunjukkan bahwa pemberian ransum yang mengandung tepung buah mengkudu sampai dengan $0,60 \%$ belum 
memberikan pengaruh yang nyata terhadap penurunan lemak abdominal, namun memberikan pengaruh yang nyata terhadap kadar kolesterol daging Ayam Sentul. Ayam Sentul sebagai penghasil daging waktu pemeliharaannya cukup lama yaitu antara 70-90 hari, sehingga biasanya sudah terbentuk perlemakan. Perlemakan yang meningkat pada tubuh ternak diikuti dengan peningkatan kadar kolesterol yang biasanya terdapat pada darah maupun dagingnya. Penambahan tepung mengkudu pada ransum ayam Sentul kemungkinan dapat menurunkan lemak yang diikuti dengan penurunan kolesterol dagingnya.

Hasil penelitian Fauzan, dkk. (2016) menunjukan bahwa penambahan tepung mengkudu dalam ransum sampai dengan $0,60 \%$ memberikan pengaruh terhadap konsumsi ransum dan konversi ransum, tetapi tidak memberikan pengaruh terhadap pertambahan bobot badan. Dari hasil penelitian dapat disimpulkan bahwa penambahan tepung mengudu sampai $0,45 \%$ dalam ransum menghasilkan performa terbaik.

\section{Produksi dan Efisiensi}

Hasil penelitian Solikin, dkk. (2016) menunjukkan bahwa rataan bobot akhir ayam Sentul jantan sebesar 896,34+ 55,46 gram dan betina $736,00+46,63$ gram, rataan bobot karkas ayam Sentul jantan 512,54 + 34,56 gram dan betina $427,67+32,41$ gram serta rataan Income Over Feed and Chick Cost ayam Sentul jantan sebesar Rp 10.416,00 dan betina Rp 6.905,00. Hasil perhitungan IOFCC ayam Sentul jantan dan betina pada penelitian ini pada jantan yaitu Rp 15.760 dan terkecil Rp 5.645, sedangkan pada betina nilai tertinggi yaitu $\mathrm{Rp} 11.840$ dan terkecil Rp 2.250. Besar kecilnya nilai IOFCC ayam Sentul umur 75 hari sebanding dengan bobot akhir ayam, semakin tinggi bobot akhir maka nilai IOFCC akan semakin tinggi. Rata-rata bobot akhir ayam Sentul Barokah Abadi Farm yang berumur 75 hari yaitu 896,34+ 96,06 gram pada ayam jantan dan $736,00+80,76$ gram betina. Hasil tersebut diperoleh dari pengambilan sampel secara acak sebanyak 15 ekor ayam Sentul jantan dan 15 ekor ayam Sentul betina. Rataan bobot karkas ayam Sentul jantan umur 75 hari hasil penelitian adalah $512,54+59,86$ gram dan betina 427,67 + 56,14 gram. Adapun persentase karkas pada jantan 57\% dan pada betina $58 \%$. Bobot karkas berkaitan erat dengan bobot akhir ayam, semakin 
besar bobot akhir ayam maka semakin besar pula bobot karkasnya.

Ayam Sentul adalah ayam lokal yang produktivitas telurnya cukup tinggi, mampu bertelur sampai 26 butir per periode bertelur, dan itu mempunyai perototan yang padat (kompak). Ayam Sentul jantan umumnya memiliki jengger tunggal (single comb) atau pea comb. Ayam Sentul juga memiliki daging yang cukup banyak. Bobot badan ayam Sentul tidak banyak berbeda dengan ayam kampung, rata-rata $2356,14 \pm 2,41 \mathrm{~g}$ untuk

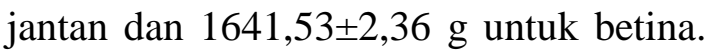
Panjang leher $20,81 \pm 1,67 \mathrm{~cm}$ untuk jantan dan 13,46 $\pm 2,32 \mathrm{~cm}$ untuk betina,

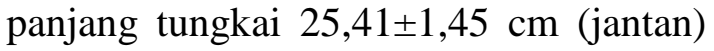
dan 23,81 $2,16 \mathrm{~cm}$ (betina), panjang punggung 23,43 $\pm 1,91$ (jantan) dan $22,87 \pm 2,24 \mathrm{~cm}$ (betina) (Nataamijaya, 2005).

Tingkat produktivitas ternak ditunjukkan dari tingkat kemampuan pertumbuhan serta kinerja reproduksinya. Nilai produktivitas pada ayam di antaranya dapat diukur dari kecepatannya bertumbuh dan berkembang yang terlihat dari tingkat kecepatan dalam mencapai suatu bobot badan tertentu dalam umur yang lebih singkat. Indikator lain terlihat dari pencapaian jumlah produksi telur yang dihasilkan dalam suatu jangka waktu tertentu (Hidayat dan Sopiyana, 2010).

Produksi telur berbagai jenis ayam Sentul yang meliputi ayam Sentul Abu, Sentul Batu, Sentul Debu, Sentul Geni dan Sentul Emas selama enam minggu secara berturut-turut adalah 18.33 btr/ekor, 19.28 btr/ekor, 13.96 btr/ekor, 12.47 btr/ekor, 10.20 btr/ekor dengan kisaran antara 8.25 sampai 21.55 btr/ekor. Hasil tersebut masih lebih rendah dibandingkan dengan potensi yang dimilikinya. Ayam Sentul mampu bertelur sebanyak 16-25 butir/periode peneluran dan \pm 150 butir/tahun (Baktiningsih, dkk., 2013).

Break Even Ponit menyatakan volume penjualan dimana total penghasilan tepat sama besarnya dengan total biaya, sehingga perusahaan memperoleh keuntungan dan juga tidak menderita kerugian. Sebelum menghitung BEP harus diketahui terlebih dahulu biaya variabel BEP dalam produk dan kemudian akan terhitung dalam rupiah. menunjukan bahwa rataan Break Even Point usaha ternak ayam Sentul sudah memenuhi kriteria yang baik, BEP dalam produk yaitu 2.844 suatu usaha peternakan ayam Sentul tidak dikatakan 
untung atau rugi dan usaha tersebut dapat berjalan dengan baik apabila rataan dapat menghasilkan BEP produk (ayam) sebanyak 2.844 ekor dalam satu tahun, dan BEP dalam rupiah Rp 10.511.491,Suatu peternakan ayam Sentul mencapai titik impas apabila mampu memperoleh rataan senyak Rp 10.511.491. Secara parsial variabel independen yang berpengaruh terhadap BEP adalah jumlah kepemilikan dan lama beternak (Hartono, dkk., 2013).

Hasil penelitian Sudrajat, dkk. (2018) menunjukkan bahwa tenaga kerja keluarga dan pengalaman berpengaruh signifikan terhadap kemampuan pemeliharaan ternak ayam Sentul, sedangkan umur dan pendidikan tidak berpengaruh signifikan terhadap kemampuan pemeliharaan ternak ayam Sentul. Hasil penelitian Isyanto dan Dehen (2016) menunjukkan bahwa kemampuan pemeliharaan ternak dipengaruhi oleh variabel tenaga kerja keluarga, curahan waktu kerja, umur, pendidikan, kredit, bimbingan teknis dan keanggotaan dalam kelompok; sedangkan variabel pengalaman tidak berpengaruh terhadap kemampuan pemeliharaan ternak. Untuk meningkatkan kemampuan pemeliharaan ternak, maka peternak dapat meningkatkan penggunaan tenaga kerja keluarga dan curahan waktu kerja, meningkatkan pendidikan non formal melalui kegiatan penyuluhan dan bimbingan teknis, membuka akses terhadap kredit, serta meningkatkan keterlibatannya dalam kelompok.

Penelitian Hartono, dkk. (2013) menunjukkan bahwa faktor-faktor yang diduga mempengaruhi tingginya angka efisiensi ekonomi yaitu jumlah ternak, biaya pakan, jumlah anggota keluarga, lama beternak, tingkat pendidikan peternak, dan tenaga kerja. Rataan jumlah kepemilikan ternak ayam Sentul yaitu sebanyak $456 \pm 483$ ekor, rataan biaya pakan ayam Sentul yaitu Rp 14.137.500 \pm 16.780 , rataan jumlah anggota keluarga yaitu $2 \pm 1.18$ orang, lama beternak ayam Sentul yaitu $6 \pm 4,25$ tahun, rataan tingkat pendidikan peternak ayam Sentul yaitu $10 \pm$ 4,325 tahun, curahan jam kerja peternak ayam Sentul yaitu sebesar 4,19 $\pm 13,11$ menit. Secara parsial variabel independen yang berpengaruh efisiensi ekonomis adalah jumlah anggota keluarga.

Hasil penelitian Isyanto, dkk (2016) menunjukkan: (1) Peternak yang inefisien dalam melaksanakan usaha ayam Sentul $(\mathrm{R} / \mathrm{C}<1)$ sebanyak 13 orang $(36,11 \%)$, 
impas $(\mathrm{R} / \mathrm{C}=1) \quad$ sebanyak 1 orang $(2,78 \%)$, dan efisien $(\mathrm{R} / \mathrm{C}>1)$ sebanyak 22 orang $(61,11 \%)$, dan (2) Faktor-faktor yang berpengaruh terhadap efisiensi usaha ayam Sentul adalah produktivitas, jumlah kepemilikan ayam, dummy pelatihan, pendidikan dan pengalaman. Efisiensi teknis, umur dan jumlah anggota keluarga tidak berpengaruh signifikan terhadap efisiensi usaha ayam Sentul. Faktor-faktor yang berpengaruh negatif dan signifikan terhadap R/C yang dicapai petenak pada usaha ayam Sentul adalah pendidikan dan pengalaman. Efisiensi teknis, umur dan jumlah anggota keluarga tidak berpengaruh signifikan terhadap R/C yang dicapai petenak pada usaha ayam Sentul.

Hasil penelitian Isyanto dan Sugianto (2017) menunjukkan bahwa faktor-faktor yang berpengaruh terhadap efisiensi usaha penggemukan sapi potong di Kabupaten Ciamis adalah pertambahan bobot badan, nilai pembelian, nilai penjualan, modal, tenaga kerja keluarga, jumlah kepemilikan ternak, dan jumlah anggota keluarga.

\section{Pendapatan Peternak}

Analisis tingkat pendapatan usaha ternak dilakukan dengan tujuan untuk melihat pendapatan pada setiap kegiatan yang diusahakan dan membandingkan masing-masing usaha. Pendapatan usaha peternakan ayam Sentul yaitu sebesar Rp 1.367.136.000. Besarnya pendapatan ayam Sentul pada penjualan ayam yaitu sebesar Rp 737.136.000. karena penjualan rataan per peternak tiap bulannya bisa menjual 70-400 ekor per bulannya dengan harga Rp 26000,- per $\mathrm{Kg}$ dengan pendapatan yang menguntungkan. Usaha peternakan ayam Sentul dijadikan usaha sampingan oleh peternak, atau kurang keseriusan peternak untuk menjalankan usaha ayam Sentul secara lebih serius. Karena permintaan ayam Sentul tiap harinya terus meningkat karena pemintaan restoran yang ada di Bandung dan Tanggerang. Secara parsial variabel independen yang berpengaruh terhadap pendapatan adalah jumlah kepemilikan, biaya pakan, dan tenaga kerja (Hartono, dkk., 2013).

Hasil penelitian Sudrajat dan Isyanto (2018) menunjukkan bahwa pendapatan peternak ayam Sentul sebesar Rp 1.435.514 yang menunjukkan bahwa usaha ternak ayam Sentul berpotensi sebagai salah satu sumber pendapatan peternak. Upaya untuk meningkatkan pendapatan peternak dapat dilakukan 
dengan peningkatan skala produksi yang perlu didukung dengan adanya kebijakan pemberian kredit produksi. Variabel jumlah kepemilikan ayam, pendidikan, jumlah tanggungan keluarga, tenaga kerja dan akses terhadap kredit berpengaruh signifikan terhadap pendapatan peternak ayam Sentul. Sedangkan umur dan pengelaman peternak tidak berpengaruh signifikan terhadap pendapatan peternak ayam Sentul. Hasil penelitian Wiranata, dkk. (2017) menunjukkan bahwa faktor yang paling dominan pengaruhnya terhadap tingkat keuntungan yaitu biaya pakan, biaya manajemen dan produksi ayam.

\section{Motivasi dan Partisipasi Peternak}

Hasil penelitian Sudrajat, dkk (2017) menunjukkan: (1) Tingkat motivasi peternak dalam memelihara ayam Sentul tergolong tinggi $(94,44 \%)$, sedangkan sisanya $(5,56 \%)$ memiliki tingkat motivasi yang rendah, dan (2) Faktor-faktor yang berhubungan signifikan dengan motivasi peternak memelihara ayam Sentul adalah pendidikan, pengalaman beternak, jumlah anggota keluarga, luas lahan pertanian, pekerjaan utama, jenis kelamin dan pelatihan. Sedangkan faktor umur tidak berhubungan signifikan dengan motivasi peternak dalam memelihara ayam Sentul.

Hasil penelitian Isyanto, $\mathrm{dkk}$. (2016) menunjukkan: (1) Tingkat partisipasi peternak ayam Sentul dalam kegiatan kelompok tergolong tinggi $(97,22 \%)$, sedangkan sisanya $2,78 \%$ memiliki tingkat partisipasi yang rendah, dan (2) Faktor-faktor yang berpengaruh terhadap partisipasi peternak ayam Sentul dalam kegiatan kelompok adalah pendidikan, pengalaman beternak, jumlah anggota keluarga, luas lahan pertanian, pekerjaan utama, jenis kelamin dan pelatihan.

\section{Strategi Pengembangan}

Ayam Sentul mempunyai beberapa keunggulan seperti pertumbuhan yang relatif cepat dan produksi telur yang tinggi jika dibandingkan dengan ayam lokal lainnya. Ayam Sentul dapat diusahakan sebagai komoditas industri untuk dikembangkan lebih lanjut sebagai ayam lokal unggul. Pengembangan ayam Sentul sangat penting dilakukan dengan mengeksplorasi potensinya dengan mempertimbangkan penurunan populasi ayam Sentul (Mugiyono, et al, 2015).

Hasil penelitian Isyanto, dkk. (2016) menunjukkan bahwa strategi 
pengembangan ayam Sentul di

Kabupaten Ciamis adalah: (1)

Meningkatkan penawaran day old chick (DOC) untuk memenuhi kebutuhan peternak, (2) Meningkatkan penawaran daging ayam melalui peningkatan populasi ayam Sentul untuk memenuhi permintaan konsumen terhadap daging ayam, (3) Pembuatan sentra produksi ayam Sentul untuk mengantisipasi tarik menarik kepentingan penggunaan lahan antara budidaya ayam Sentul dengan pemukiman serta untuk memudahkan di dalam monitoring kesehatan ayam Sentul, (4) Peningkatan jumlah kepemilikan ayam Sentul per peternak melalui skema kredit program dengan penekanan pada kegiatan monitoring dan evaluasi agar tepat pada tujuan dan sasaran, (5) Peningkatan kemampuan teknis peternak dalam memelihara ayam Sentul melalui kegiatan penyuluhan, pelatihan maupun bimbingan teknis untuk meningkatkan produktivitas, (6) Peningkatan efisiensi dan produktivitas melalui kebijakan produksi yang didukung dengan koordinasi lintas sektoral yang baik, (7) Pemberian subsidi produksi untuk menjamin kelangsungan produksi agar tidak terpengaruh secara signifikan oleh fluktuasi harga sarana produksi, dan (8)
Peningkatan kemampuan manajemen peternak dalam hal kesehatan ayam Sentul melalui kegiatan penyuluhan, pelatihan maupun bimbingan teknis untuk mendukung tercapainya efisiensi dan produktivitas yang tinggi.

Pengembangan ayam lokal di Indonesia hendaknya diarahkan pada peningkatan skala kepemilikan dan perbaikan teknik budi daya dengan mengubah pola pemeliharaan dari pola ekstensif tradisional (sistem umbaran) ke usaha intensif komersial sehingga dapat meningkatkan pendapatan petani dan kesempatan kerja. Upaya pengembangan tersebut diharapkan pula dapat menggairahkan perekonomian dan sekaligus meningkatkan pendapatan masyarakat, terutama di perdesaan, karena Indonesia memiliki sumber daya alam yang memadai untuk menciptakan bibit unggul, bahan pakan, dan obatobatan yang dibutuhkan dalam industri peternakan ayam modern, intensif, dan efisien (Nataamijaya, 2010).

\section{PENUTUP}

Ayam Sentul merupakan ayam asli Kabupaten Ciamis yang memiliki keunggulan dalam pertumbuhan bobot badan dan produksi telur sehingga 
memiliki potensi untuk dikembangkan dalam upaya meningkatkan pendapatan peternak.

\section{DAFTAR PUSTAKA}

Afriani, H., Idris, N. dan Fatati. 2014. Minat dan Motivasi Peternak Untuk Mengembangkan Ternak Sapi Pada Kawasan Perkebunan Kelapa Sawit di Propinsi Jambi. Jurnal Ilmiah Ilmu-Ilmu Peternakan, XVII(2): 77-83.

Akhadiarto, S. 2017. Kajian Pembuatan Pakan Lokal Dibanding Pakan Pabrik Terhadap Performan Ayam Kampung Di Gorontalo. M.P.I. 11(1): 41-50.

Andjarwati, T. 2015. Motivasi dari Sudut Pandang Teori Hirarki Kebutuhan Maslow, Teori Dua Faktor Herzberg, Teori X Y Mc Gregor, dan Teori Motivasi Prestasi Mc Clelland. JMM17 Jurnal Ilmu Ekonomi \& Manajemen, 1(1): 4554.

Baktiningsih, S., Mugiyono, S. dan Saleh, D.M. 2013. Produksi Telur Berbagai Jenis Ayam Sentul Di Gabungan Kelompok Tani Ternak Ciung Wanara Kecamatan Ciamis
Kabupaten Ciamis. Jurnal Ilmiah Peternakan, 1(3): 993-1000.

Ermansyah, G., Tanwiriah, W. dan Asmara, I.Y. 2015. Pengaruh Pemberian Tepung Ampas Tahu Di Dalam Ransum Terhadap Bobot Potong, Bobot Karkas Dan Income Over Feed Cost Ayam Sentul. Students e-Journal Fakultas Peternakan Universitas Padjadjaran, 4(4): 1-6.

Fadly, M., Tanwiriah, W. dan Asmara, I.Y. 2016. Pengaruh Pemberian Tepung Buah Mengkudu (Morinda citrifolia L.) Dalam Ransum Terhadap Lemak Abdominal Dan Kadar Kolesterol Daging Ayam Sentul (Gallus domestica). Students e-Journal Fakultas Peternakan Universitas Padjadjaran, 5(4): 110.

Fauzan, R., Tanwiriah, W. dan Asmara, I.Y. 2016. Pengaruh Penambahan Tepung Mengkudu Dalam Ransum Terhadap Performa Ayam Sentul. Students e-Journal Fakultas Peternakan Universitas Padjadjaran, 5(4): 1-10.

Hartono, E.F., Hidayat, N.N. dan Roesdiyanto. 2013. Kinerja Ekonomi Usaha Ayam Sentul di 
Kabupaten Ciamis. Jurnal Ilmiah Peternakan, 1(3): 865-873.

Hidayat, C. dan Sopiyana, S. 2010. Potensi Ayam Sentul Sebagai Plasma Nutfah Asli Ciamis Jawa Barat.

Hidayat, C., Sumiati dan Iskandar, S. 2015. Persentase Bobot Karkas dan Potongan Komersial Ayam SentulG3 yang Diberi Ransum Mengandung Dedak Tinggi dengan Suplementasi Fitase dan $\mathrm{ZnO}$. Jurnal Ilmu Pertanian Indonesia (JIPI), 20 (2): 131-140.

Indra, I., Tanwiriah, W. dan Widjastuti, T. 2015. Bobot Potong, Karkas, Dan Income Over Feed Cost Ayam Sentul Jantan Pada Berbagai Umur Potong. Students e-Journal Fakultas Peternakan Universitas Padjadjaran, 4(3): 1-10.

Isyanto, A.Y. dan Dehen, Y.A. 2016. Faktor-faktor yang Berpengaruh Terhadap Kemampuan Pemeliharaan Ternak Sapi Potong di Kabupaten Ciamis. Prosiding Seminar Nasional Hasil Penelitian Pertanian 2015, Fakultas Pertanian Universitas Gadjah Mada. pp. 725730.
Isyanto, A.Y. dan Sugianto, I. 2017. Faktor-faktor yang Berpengaruh Terhadap Efisiensi Usaha Penggemukan Sapi Potong di Kabupaten Ciamis. Prosiding Seminar Nasional Hasil Penelitian Pertanian VI 2016, Fakultas Pertanian Universitas Gadjah Mada. pp. 235-239.

Isyanto, A.Y., Sudrajat, S. dan Iskandar, M. 2016. Faktor-faktor yang Berpengaruh Terhadap Efisiensi Usaha Ayam Sentul di Kabupaten Ciamis. Mimbar Agribisnis, 1(3): 197-202.

Isyanto, A.Y., Sudrajat dan Iskandar, M. 2016. Faktor-faktor yang Berpengaruh Terhadap Partisipasi Peternak Ayam Sentul dalam Kegiatan Kelompok (Kasus di Kabupaten Ciamis). Prosiding Seminar Nasional Hasil Penelitian Sosial Ekonomi Pertanian Departemen Sosial Ekonomi Pertanian, Fakultas Pertanian Universitas Gadjah Mada. pp. 679684.

Isyanto, A.Y., Sudrajat, S. dan Iskandar, M. 2016. Strategi Pengembangan Ayam Sentul di Kabupaten Ciamis. Mimbar Agribisnis, 3(1): 1-12. 
Mariandayani, H.N., Darwati, S., Sutanto, E. dan Sinaga, E. 2017. Peningkatan Produktivitas Ayam Lokal Melalui Persilangan Tiga Rumpun Ayam Lokal pada Generasi Kedua. Prosiding Seminar Nasional Biologi 2017, Pendidikan Biologi untuk Masa Depan Bumi, Jurusan Pendidikan Biologi, Universitas Syiah Kuala, 11 November 2017. pp. 139-146.

Mariandayani, H.N., Solihin, D.D., Sulandari, S. dan Sumantri, C. 2013. Keragaman Fenotipik dan Pendugaan Jarak Genetik pada Ayam Lokal dan Ayam Broiler Menggunakan Analisis Morfologi. Jurnal Veteriner, 14(4): 475-484.

Marpaung, R. 2013. Pengaruh Kepemimpinan dan Motivasi Terhadap Semangat Kerja Pegawai Dinas Pertanian, Peternakan dan Perikanan Kabupaten Siak. Jurnal Ekonomi, 21(2): 1-16.

Melis, Muthalib, A.A. dan Apoda. 2016. Analisis Partisipasi Masyarakat Dalam Pembangunan Desa (Studi di Desa Wawolesea Kecamatan Lasolo Kabupaten Konawe Utara). Jurnal Ekonomi (JE), 1(1): 99-105.
Meyliyana, Mugiyono, S. dan Roesdiyanto. 2013. Bobot Badan Berbagai Jenis Ayam Sentul Di Gabungan Kelompok Tani Ternak Ciung Wanara Kecamatan Ciamis Kabupaten Ciamis. Jurnal Ilmiah Peternakan, 1(3): 985-992.

Mugiyono, S., Saleh, D.M. dan Sukardi. 2015. Reproductive Performance of Various Breeds of Sentul Chicken. Animal Production, 17(3): 169-176. Muharlien, V.M. dan Nurgiartiningsih, A. 2015. Pemanfaatan Limbah Daun Pepaya Dalam Bentuk Tepung dan Jus Untuk Meningkatkan Performans Produksi Ayam Arab. Research Journal of Life Science, 02(02): 93-100.

Nataamijaya, A.G. 2005. Karakteristik Penampilan Pola Warna Bulu, Kulit, Sisik Kaki, dan Paruh Ayam Pelung di Garut dan Ayam Sentul di Ciamis. Buletin Plasma Nutfah, 11(1): 1-6.

Nataamijaya, A.G. 2010. Pengembangan

Potensi Ayam Lokal Untuk Menunjang Peningkatan Kesejahteraan Petani. Jurnal Litbang Pertanian, 29(4): 131-138. Nazir, M. 2005. Metode Penelitian. Jakarta: Ghalia Indonesia. 
Peranginangin, L.S.U. 2014. Partisipasi

Masyarakat dalam Pengelolaan

Kawasan Konservasi. Jurnal

Kebijakan \& Administrasi Publik. JKAP, 18(1): 66-78.

Royani, M. 2016. Pengaruh Subtitusi Ransum Komersil Dengan Jagung Terhadap Bobot Potong Dan Income Over Feed And Chick Cost Ayam Sentul. Jurnal Ilmu Peternakan (JANHUS), 1(1): 1723.

Solikin, T., Tanwiriah, W. dan Asmara, I.Y. 2016. Bobot Akhir, Bobot Karkas, Dan Income Over Feed And Chick Cost Ayam Sentul Barokah Abadi Farm Ciamis. Students e-Journal Fakultas Peternakan Universitas Padjadjaran, 5(4): 1-9.

Sudrajat, S. dan Isyanto, A.Y. 2018. Faktor-faktor yang Berpengaruh Terhadap Pendapatan Usaha Ternak Ayam Sentul di Kabupaten Ciamis. Mimbar Agribisnis: 4(1): 70-83.

Sudrajat, Isyanto, A.Y. dan Iskandar, M. 2017. Faktor-faktor yang Berhubungan dengan Motivasi Peternak dalam Memelihara Ayam Sentul di Kabupaten Ciamis.
Prosiding Seminar Nasional Hasil Penelitian Pertanian VI 2016, Fakultas Pertanian Universitas Gadjah Mada. pp. 225-229.

Sudrajat, Sujaya, D.H., Isyanto, A.Y., Ramdan, M. dan Aziz, S. 2018. Faktor-faktor yang Berpengaruh Terhadap Kemampuan Pemeliharaan Ternak Ayam Sentul di Kabupaten Ciamis. Prosiding Seminar Nasional Hasil Penelitian Agribisnis II, Program Studi Agribisnis, Fakultas Pertanian Universitas Galuh. pp: 165-169.

Sugiyono. 2012. Memahami Penelitian Kualitatif. Bandung: Alfabeta.

Suhardi. 2011. Karakterisasi Ex Situ Ayam Lokal Khas Dayak Bagi Pengembangan Plasma Nutfah Ternak Unggas Nasional. Jurnal Teknologi Pertanian,7(1):36-41.

Susanto, E. dan Suliswanto. 2013. Pengaruh Berat Telur Terhadap Daya Tetas Telur Ayam Kampung. Jurnal Ternak, 04(02): 27-30.

Widjastuti, T. 2009. Pemanfaatan Tepung Daun Pepaya (Carica Papaya.L L Ess) dalam Upaya Peningkatan Produksi dan Kualitas Telur Ayam Sentul. J. Agroland, 16(3): 268273. 
Wiranata, M.A., Sanyoto, J.I. dan Subagja, H. 2017. Analisis Profitabilitas Usaha Peternakan Ayam Kampung Super Di Kabupaten Jember. Jurnal Imu Peternakan Terapan, 1(1): 31-38.
Yoko, B., Syaukat, Y. dan Fariyanti, A. 2014. Analisis Efisiensi Usahatani Padi Di Kabupaten Lampung Tengah. Jurnal Agribisnis Indonesia, 2(2): 127-140. 